\title{
THE INFLUENCE OF FEMALE DIRECTOR ON THE PROBABILITY OF COMPANIES EXPERIENCING FINANCIAL DISTRESS
}

\author{
Stephanie Angelina Koerniawan ${ }^{1}$, Mariana Ing Malelak ${ }^{2}$ \\ 1,2 Finance and Investment Program \\ Faculty of Business and Economics, Petra Christian University \\ JI. Siwalankerto 121-131, Surabaya \\ E-mail: ${ }^{1} \mathrm{~m} 37416048 @ j o h n . p e t r a . a c . i d ;{ }^{2}$ mariana.ing@petra.ac.id
}

\begin{abstract}
This study aims to determine the effect of Female Director on the Probability of a Company Experiencing Financial Distress. Springate model is used to predict the probability of a company experiencing financial distress. This study compares the effect of female director on the probability of a company experiencing financial distress without control variables and using control variables. The control variables in this study are board size, firm size and leverage. The population in this study were manufacturing companies listed on the Indonesia Stock Exchange in the period 2013-2018. The samples in this study were 27 companies. The results of this study indicate that female directors have no significant effect on the probability of a company experiencing financial distress. By using control variables, it is shown that female directors do not significantly influence the probability of a company experiencing financial distress with the control variables such as board size, firm size, and leverage.
\end{abstract}

Keywords: Female director, financial distress, board size, firm size, leverage.

\section{INTRODUCTION}

The problem that is closely related to the company's financial condition is financial distress. This financial distress refers to the company's declining financial condition, or in other words, in this condition, the company is experiencing liquidity difficulties and a decreased ability to fulfill its obligations to creditors (Hanifah, 2013).

One of the parameters used to predict financial distress is to use the Springate model. This Springate model has four calculations that can measure the company's liquidity, profitability, and operational efficiency. If the value is Springate $\geq 0.862$, the company is included in the category of healthy or non-companies' financial distress, and if the value is Springate $\leq 0.862$, then the company is included in the category of unhealthy companies or experiencing financial distress. According to the results of previous research conducted by Sinarti and Sembiring (2015) in predicting financial distress using the Springate model, it is stated that there are manufacturing companies that have a probability of experiencing financial distress, namely PT Alumindo Light Metal Industry Tbk in 2009 and PT Indah Aluminum Industry in 2009 and 2011 with a value Springate below $\leq 0.862$. With the results of these studies, companies need to carry out risk management to predict and analyze company finances. Risk management has an essential role in realizing good corporate governance. Realizing good corporate governance will protect the company against the risk of financial distress (Tanujaya, Samuel and Devie, 2017).

In implementing good corporate governance, the board of directors has an important role (Anggala \& Basana, 2020). The board of directors will be responsible for a wide variety of corporate affairs and decision-making. In addition, the diversity of the board of directors is an essential component in realizing good corporate governance (Roika, Salim and Sumiati, 2019). The diversity board of directors looks at the gender diversity on the board of directors of the company. Men are still considered the right choice in occupying a senior position such as a board of directors in a company. But with the development of information and technology, nowadays women can occupy senior positions in companies. 
Senior positions such as director of a company led by women can reduce the probability of a company experiencing financial distress. According to previous research, it is stated that the characteristics possessed by women and men are different, such as in decision making, risk avoidance, and risk tolerance. Thus, having a female director affects helping reduce the probability of a company experiencing financial distress.

\section{LITERATURE REVIEW}

\section{Financial Distress}

Financial distress is a condition of financial difficulty that may be the beginning of bankruptcy (Gamayumi, 2011). Springate model is used to predict the probability of a company experiencing financial distress. In the calculation of the Springate model, there are four ratios, namely working capital to total assets, EBIT to total assets, EBIT to current liabilities, and sales to total assets. By having provisions, if the value is Springate $\geq 0.862$, the company is included in the category of healthy or non-financial distress companies, and if the value is Springate $\leq 0.862$, then the company is included in the category of unhealthy companies or experiencing financial distress.

\section{Female Director}

The success and failure of women to become directors in organizations is not due by luckiness. According to Faras (1995), the success and failure of women are not solely due to cultural factors, but three other factors influence, namely motivational factors, educational factors, and experience factors in organizations. Therefore, with the hard work and efforts made by women to achieve success, women today can occupy senior positions in companies, one of which is director.

\section{Corporate Governance}

According to Monk and Minow (2001) in Nuryaman (2008), corporate governance is a control mechanism in regulating and managing a company to increase the company's prosperity and accountability with the hope of realizing shareholder value.

\section{Resource Dependence Theory}

Resource Dependence Theory states that the board Directors will bring resources such as information, expertise, key constituents (suppliers, buyers, public policy decision-makers, social groups), and legitimacy, which will help to reduce uncertainty (Gales and Kesner, 1994).

\section{Managerial Ownership}

Managerial Ownership is the number of shares owned by management (board of directors) of all share capital in the company (Sartono, 2010).

\section{Gender Diversity}

Gender is a set of characteristics associated with a person's gender and directed at their social role or identity in society (Armas, 2016). This relationship between gender questions the position of women and men in the distribution of resources and responsibilities, benefits, rights, and powers (Sumiarni, 2005).

\section{Board Size}

The board of directors and the board of commissioners are the parties that are responsible and have full authority in making decisions about directing, controlling, and supervising resource management by company objectives (Sari and Ardiana, 2014). According to the National Committee on Governance (2006), the number of board members must be adjusted to the company's complexity while still paying attention to effectiveness in decision-making. 


\section{Firm Size}

Firm Size is a picture of the company's size (Anggala \& Basana, 2020), which is reflected in the total value of the company's assets on the balance sheet at the end of the year as measured by len (Ln) of total assets (Sujoko and Soebiantoro, 2007; Shanthana \& Basana, 2020). Leverage is the ratio used to calculate how much the company's assets are financed by debt (Kasmir, 2012).

\section{Relationship between Concepts}

\section{The Influence of Female Director on the Probability of Companies experiencing Financial Distress.}

The existence of female directors in the company affects the probability of the company experiencing financial distress. This is because of the characteristics possessed by women, namely having the ability to review risks, be more careful in handling risks than men, and consider decisions in detail before making big decisions for companies (Jing, 2019).

In theory, managerial ownership, female directors can monitor because they have share ownership in the company. With the increasing share ownership owned by the female director, it will have the same goals or interests as the shareholders to reduce the probability of the company experiencing financial distress. Research conducted by Ningrum and Hatane (2017) shows that female directors have a significant negative effect on corporate financial distress. But on the other hand, according to research (Sholikhah, 2018), the number of female directors does not affect financial distress.

\section{The Influence of Female Director on the Probability of Companies Experiencing Financial Distress with Board Size as Control Variable}

Board Size influences the probability of companies experiencing financial distress. Based on the perspective of resource dependence theory, with large board size, there will be more external relations and diversification of expertise which can protect the company from financial distress (Goodstein, 1994; Zahra and Pearce, 1989). Therefore, the number of the board of directors has a positive effect on financial distress (Kristian, 2017).

However, large board sizes tend to be less effective than small board sizes (Meizaroh and Lucyanda, 2011). Therefore, according to Bodroastuti (2009), the size of the board of directors has a significant negative effect on financial distress.

\section{The influence of Female Director Probability Against Corporate Experienced Financial Distress by Firm Size for Control Variables}

Firm Size (size of the company) was great to have stronger financial fundamentals than small companies that are not vulnerable when subjected to financial shocks (Ward, 2007; Shanthana \& Basana, 2020). Thus, the larger the firm size, the smaller the risk of the company experiencing financial distress so that the size of the company affects financial distress (Nora, 2016).

The presence of female directors in the company is expected to minimize risk by helping to choose suitable decision-making methods to avoid risks. This is because, according to Cinantya and Merkusiwati (2015) it shows that company size does not affect financial distress.

\section{The influence of Female Director Probability Against Corporate Experience Financial Distress with Leverage Control Variables}

Leverage analysis is required to measure the company's ability to pay short-term debt and long term. If the financing company uses more debt, there will be a risk of financial distress in the future. Therefore, based on research conducted by Jiming and Wei (2012), it is stated that leverage has a significant effect on conditions of financial distress. But according to a study by Carolina (2017), 
the ratio leverage is having no significant impact on financial distress. With the presence of female directors in the company, it is hoped that before deciding to take debt, they can analyze its finances and see the economic situation.

\section{Thinking Framework}

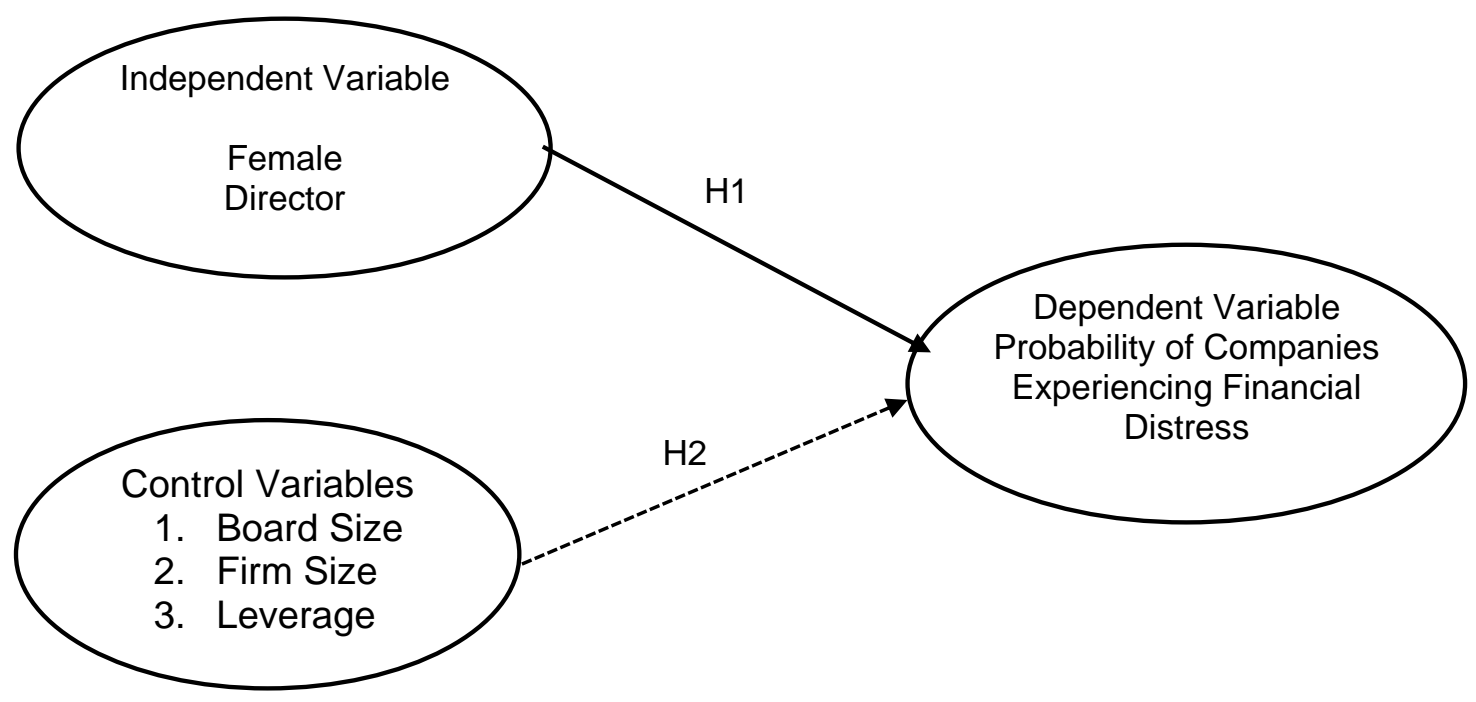

Figure 1. Framework of Research

\section{Research Hypothesis}

$\mathrm{H}_{1}$ : Female director has a significant effect on the probability of the company experiencing financial distress.

$\mathrm{H}_{2}$ : Female director has a significant effect on the probability of a company experiencing financial distress with Board Size, Firm Size, and Leverage as control variables.

\section{METHODOLOGY}

\section{Population and Sample Description}

The population in this study are manufacturing companies in Indonesia listed on the Indonesia Stock Exchange (IDX). This study uses a sample of manufacturing companies from the Indonesia Stock Exchange (IDX) in 2013-2018, which provide annual reports and financial reports regularly in 2013-2018, and companies with consecutive female boards of directors in 2013-2018.

\section{Operational Definition of Variables}

The dependent and independent variables in this study are as follows:

Concept: The probability of a company experiencing financial distress

Operational definition: A company that has a low ratio of profitability, liquidity and asset turnover.

Empirical indicators:

$S=1.03 A+3.07 B+0.66 C+0.4 D$

There are four calculations used, namely:

$A=$ Working capital / Total Asset

$\mathrm{B}=$ Net profit before interest and taxes / Total assets

$\mathrm{C}=$ Net profit before taxes / Current liabilities

$\mathrm{D}=$ Sales $/$ Total Asset 


\section{Provisions:}

With a cut-off, if the value is Springate $\geq 0.862$, the company is categorized as a company healthy or non-financial distress. If the value is Springate $\leq 0.862$, the company is categorized as an unhealthy company or experiencing financial distress.

Concept: Female Director (Variable Dependent)

Operational Definition: Proportion of the number of women who occupy a position on theboard of directors' company's.

$$
\text { Empirical Indicators: } F D=\frac{\text { Number of female directors }}{\text { Total number of directors }}
$$

In addition, this study uses three control variables, namely board size, firm size, and leverage.

Concept : Board Size

Operational Definition : Number of members of the board of directors in the company

Empirical indicator : Total number of boards of directors in the company
Concept
: Firm Size
Operational Definition : Size of a company as seen from total assets.
Empirical Indicator : Ln (total assets)

Concept: Leverage

Operational Definition : Measure the debt composition by the total assets of the company.

Empirical Indicators : $\frac{\text { total liabilities }}{\text { total assets }}$

\section{Data Analysis Techniques}

This study uses regression test binary logistic (companies experiencing financial distress are coded 1 (one) and companies that do not experience financial distress 0 (zero)). The following is the logistic regression test model in this study as follows:

$$
\operatorname{Ln}\left(\frac{\pi}{(1-\pi)}\right)=\alpha+\beta_{1}(\text { FD })+\beta_{2}(\text { BRDSIZE })+\beta_{3}(\text { FSIZE })+\beta_{4}(\text { LEV })+\varepsilon
$$

Information:

$$
\begin{array}{ll}
\pi_{0} & =\text { Firm with financial distress (springate value } \leq 0.862) \\
\pi_{1} & =\text { Firm with no financial distress }(\geq \text { springate value } 0,862) \\
\alpha & =\text { coefficient of constants } \\
\beta 1-\beta 4 & =\text { logistic regression coefficient } \\
\varepsilon & =\text { Error }
\end{array}
$$

\section{RESULTS AND DISCUSSION}

The data collection companies that match the criteria there is 27 company sample with a total of 162 financial statement data used.

Table 1. Descriptive Data of Manufacturing

\begin{tabular}{lllll}
\hline & $N$ & Min & Max & Mean \\
\hline FD & 162 & 0077 & 0667 & 0.30007 \\
BED SIZE & 162 & 2 & 16 & $5: 51$ \\
SIZE & 162 & $49,433,362$ & 27645119037440.00 & $351,721,210,114,446$ \\
LEV & 162 & 0022 & 3029 & 0.49584 \\
Probability of companies & 162 & 0 & 1 & $0: 40$ \\
experiencing financial distress & 162 & 0 & 1 & \\
\hline
\end{tabular}

The above table shows that the average FD of 0.30007 , the average BRDSIZE was 5.51, the average FSIZE was IDR $351,721,210,114,446$, the average LEV was 0.49584 , and the average probability of companies experiencing financial distress was 0.40 . 
Next, the researcher conducted a two-stage logistic regression test. First, to test the influence of Female directors on the probability of the company experiencing financial distress. Second, to test the impact of the female director on the probability of the company experiencing financial distress with the control variables: board size, Firm Size, and Leverage.

Table 2. Results Omnibus Test of Model Coefficients

\begin{tabular}{llll}
\hline Stage 1 & & & \\
\hline Model & Method & Significance & Conclusion \\
\hline FD & Omnibus of Model Coefficients test & 0.520 & $p$-value $>0.05$, then H0 is accepted \\
\hline Stage 2 & & & \\
\hline FD & & & p-value $>0.05$, then $\mathrm{H} 0$ is accepted \\
BED SIZE & Omnibus of Model Coefficients test & 0.068 & \\
SIZE & & & \\
LEV & &
\end{tabular}

As shown in table 2 , stage 1 states that $\mathrm{H}_{0}$ is accepted so that the variable Female Director does not have a simultaneous influence on the company's probability of experiencing financial distress. For the stage 2 test, the variables Female Director, Board Size, Firm Size, and Leverage do not have a simultaneous influence on the probability of the company experiencing financial distress.

Table 3. Nagelkerke R Square Test Results

\begin{tabular}{llll}
\hline Stage 1 & & & \\
\hline Model & Method & Significance & Conclusion \\
\hline FD & Nagelkerke R Square & 0.003 & $p$-value $<0.05$, then $\mathrm{H} 0$ is accepted \\
\hline Stage 2 & & & \\
\hline FD & & 0.071 & $p$-value $>0.05$, then $\mathrm{H} 0$ is rejected \\
BED SIZE & Nagelkerke R Square & & \\
SIZE & & & \\
LEV & &
\end{tabular}

As shown in table 3 , stage 1 , the significance value is 0.003 , which means less than 0.05 . The model cannot explain the influence of variables Female Director on probability the company experiences financial distress. For the stage 2 test, the significance value is 0.071 , which means more than 0.05. The model can explain the influence of the variables Female Director, Board Size, Firm Size, and Leverage on the probability the company experiences financial distress.

Table 4. The results of the Hosmer and Lemeshow test

\begin{tabular}{|c|c|c|c|c|}
\hline Stage 1 & & & & \\
\hline Model & Method & Significance & Chi-Square & Conclusion \\
\hline FD & Hosmer and Lemeshow Test & 0.683 & 3.955 & $\mathrm{p}$-value $>0.05$, then $\mathrm{HO}$ is accepted \\
\hline Stage 2 & & & & \\
\hline $\begin{array}{l}\text { FD } \\
\text { BED SIZE } \\
\text { SIZE } \\
\text { LEV }\end{array}$ & Hosmer and Lemeshow Test & 0.029 & 17.105 & $\mathrm{p}$-value $<0.05$, then $\mathrm{H} 0$ is rejected \\
\hline Stage 2.1 & & & & \\
\hline $\begin{array}{l}\text { FD } \\
\text { BED SIZE } \\
\text { SIZE } \\
\text { LEV }\end{array}$ & Hosmer and Lemeshow Test & 0.063 & 14.808 & $\begin{array}{l}\mathrm{p} \text {-value }>0.05 \text {, then } \mathrm{H} 0 \text { is accepted } \\
\text { by }\end{array}$ \\
\hline
\end{tabular}

It can be seen in table 4 , stage 1 , which states that the model has a significance value of more than 0.05 , so it receives $\mathrm{H}_{0}$. Thus, the hypothesized model is fitted with the data. But in the stage 2 test, the significance value is less than 0.05 , so that it rejects $\mathrm{H}_{0}$, which indicates that the model is unacceptable. Therefore, to overcome this, we can add an interaction variable between the independent variables. In stage 2.1, after adding the interaction variable, the significance value 
becomes 0.063 , which means it is greater than 0.05 so that the hypothesized model fits with the data.

Table 5. Table Classification

\begin{tabular}{ccccc}
\hline \multirow{2}{*}{$\begin{array}{c}\text { The probability of a } \\
\text { company experiencing } \\
\text { financial distress }\end{array}$} & $\begin{array}{c}\text { Probability of a company experiencing } \\
\text { financial distress }\end{array}$ & $\begin{array}{c}\text { Percentage } \\
\text { Correct }\end{array}$ \\
\cline { 2 - 5 } & $\begin{array}{c}\text { Does not experience } \\
\text { financial distress } \\
\text { financial distress }\end{array}$ & 98 & $\begin{array}{c}\text { Experiencing } \\
\text { financial distress }\end{array}$ & \\
\cline { 2 - 5 } & $\begin{array}{c}\text { Experiencing financial } \\
\text { distress }\end{array}$ & 64 & 0 & 100 \\
\hline \multicolumn{5}{c}{ Overall Percentage } \\
\hline
\end{tabular}

Classification tables in stage 1 and stage 2 have the same results, so it can conclude that This logistic regression equation can predict the probability of a company experiencing financial distress of $60.5 \%$.

Table 6. Wald Test

\begin{tabular}{lcccc}
\hline Stage 1 & \multicolumn{3}{c}{} & \\
\hline Model & $\mathrm{B}$ & Significance & & Exp (B) \\
\hline FD & -0.849 & 0.523 & Not Significant & 0.428 \\
\hline Stage 2 & & & & \\
\hline FD & -1.189 & 0.417 & Not Significant & 0.304 \\
BED SIZE & -0.053 & 0.434 & Not Significant & 0.948 \\
SIZE & -0.059 & 0.238 & Not Significant & 0.943 \\
LEV & 0.801 & 0.063 & Not Significant & 2,228 \\
\hline
\end{tabular}

Based on the above research results, female directors, board size, firm size, and leverage do not significantly affect the probability of companies experiencing financial distress. The results in this study are in line with the research of Ningrum and Hatane (2017), Ferbienti (2017), Cinantya and Merkusiwati (2015), Sastriana and Fuad (2013), and Pulungan (2017).

\section{CONCLUSIONS AND RECOMMENDATIONS}

Based on this study, it can be concluded that female directors do not affect the probability of companies experiencing financial distress. Female directors do not affect the probability of companies experiencing financial distress with control variables of board size, firm size, and leverage. Suggestions that further researchers can give are to enlarge the research object by all manufacturing companies. And the other independent variables such as conducting research on male directors and comparing the presence of men and women on the company's board of directors to the probability of the company experiencing financial distress.

\section{REFERENCES}

Anggala, A. \& Basana, S.R. (2020). Pengaruh related party transaction terhadap nilai perusahaan. International Journal of Financial and Investment Studies (IJFIS), 1(1), 42-52. https://doi.org/10.9744/ ijfis.1.1.42-52

Armas, S. (2016). The Influence of Gender Diversity, Directors' Remuneration and Ownership Structure on the Performance of Companies Listed on the IDX for the 2011-2013 Period. Lampung University.

Bodroastuti, T. (2009). The Effect of Corporate Governance Structure on Financial Distress. Journal of Accounting Research, Management, Economics. 1 (1), 87-105.

Carolina (2017). Advanced Financial Accounting (Indonesian Perspective) Advanced Financial Accounting. Salemba Empat

Cinantya, I.G., \& Merkusiwati, N.K. (2015). The Influence of Corporate Governance, Financial Indicators and Company Size on Financial Distress. E-Journal of Accounting Universias Udayana, 897-915.

Faras, NJ (1995). Leadership of women leaders in women's organizations. Educational journal. 80.

Ferbienti, F. (2017). Effect of the Structure of the Board of Commissioners, Institutional Ownership and Characteristics of the Audit Committee on Financial Distress. Thesis. Faculty of Economics and Business. Lampung University. Bandar Lampung 
Gales, L.M., \& Kesner, I.F. (1994). An analysis of the board of director size \& composition in bankrupt organizations. Journal of Business Research, 30 (3), 271-282

Gamayumi (2011). Analysis of the Accuracy of Altman's Model as a Tool to Predict Bankruptcy. (Empirical Study on Manufacturing Companies Listed on the Indonesian Stock Exchange). Journal of Accounting and Finance. Faculty of Economics, University of Lampung.

Goodstein, J., Gautam, K., Boeker, W. (1994). The effect of board size and diversity on strategic change. Strategic Management Journal. 15, 241-250..

Hanifah, O.E. (2013). The Effect of Corporate Governance Structure and Financial Indicators on Financial Distress Conditions (Study of manufacturing companies listed on the Indonesia Stock Exchange in 2008-2010). Diponegoro University.

Hatane, E and Hamdani, Y. (2017). Effect of the Board of Directors on Firm Value through Firm Performance as an Intervening Variable. Business Accounting Review, 5 (1), 121-132.

Jiming, Li \& Wei, D. (2012). An Empirical Study on the Corporate Financial Distress Prediction Based on Logistic Model Evidence from China's Manufacturing Industry. International Journal of Digital Content Technology. 5 (6)

Cashmere. (2010). Introduction to Financial Management. Jakarta: Kencana Penata Media Group.

Khakim, A. (2014). Basics of Indonesian Manpower Law.

National Committee on Governance Policy. (2006). General Guidelines for Indonesian Good Corporate Governance.

Kristian, M. (2017) The effect of the number of boards of directors and shareholder equity to total asset ratio on financial distress. Journal of Economics, 22 (3), 351-365

Meizaroh and Lucyanda, J. (2011). The Influence of Corporate Governance and Ownership Concentration on Enterprise Risk Management Disclosure. Accounting National Symposium. Bakrie University Jakarta: Aceh, 1-30

Ningrum, A \& Hatane, S. (2017). The influence of Corporate Governance on financial distress. Journal of business accounting, $5(1), 241-252$.

Nora, A.R. (2016). The Influence of Financial Indicators, Company Size and Institutional Ownership on Financial Distress. Perbanas School of Economics' Scientific Articles.

Nuryaman, (2008). The influence of ownership concentration, firm size and corporate governance mechanisms on earnings management, Pontianak: Accounting National Symposium.

Pulungan, KPA (2017). The effect of liquidity and leverage on financial distress in ceramics, porcelain and glass sub-sector companies listed on the Indonesian stock exchange. Journal of Financial. 3 (2).

Roika, R., Salim, U., Sumiati, S. (2019). The Effect of Diversity of the Board of Directors on the Company's Financial Performance. lqtishoduna. 15 (2). 115-128.

Sari, AA Pt. Agung Mirah Purnama and Ardiana, PA (2014). Effect of Board Size on Firm Value. E-Journal of Accounting at Udayana University. 177-191.

Sartono, A. (2010). Financial Management Theory and Applications. 4th Edition Yogyakarta: BPFE

Sastriana, D and Fuad (2013). The Influence of Corporate Governance and Firm Size on Companies with Financial Distress (Financial Distress. E-Journal of Accounting, 1 (7), 93-106

Sekaredi, Sawitri (2011). The Effect of Corporate Governance on CorporatePerformance Financial. Diponegoro University, Semarang.

Shanthana, L.S. \& Basana, S.R. (2020). pengaruh firm size terhadap leverage pada perusahaan manufaktur publik Indonesia periode 2013-2017. International Journal of Financial and Investment Studies (IJFIS), 1(1), 53-66. https://doi.org/10.9744/ijfis.1.1.53-66

Sholikhah, P.N. (2018). Analysis of the influence of CEO Gender, CEO Quality, Generation Family Firm on Financial Distress in Family Companies. Thesis. Management. Finance. Islamic University of Indonesia. Yogyakarta.

Sinarti \& Sembiring (2015). Bankruptcy Prediction Analysis of Listed Manufacturing Companies in Indonesia Stock Exchange. International Journal of Economics and Financial Issues, 354-359

Sujoko and Soebiantoro, U. (2007) Influence of Share Ownership Structure, Leverage, Internal Factors and External Factors on Firm Value. Journal of Management and Entrepreneurship. 9 (1) .

Sumiarni, E. (2005). the position of husband and wife in marriage law (assessment of gender equality through mating agreement. Yogyakart a: Jalasutra.

Tanujaya, L.R., Samuel, H., Devie. (2017). Analysis of the Influence of Corporate Governance, CSR, and Financial Distress on Firm Value in Companies Listed on the IDX 2011-2015. Petra Business \& Management Review, 3 (1).

Wardhani, R. (2007). Corporate Governance mechanisms in companies experiencing financial problems. Indonesian Journal of Accounting and Finance. 4 (1), 95-114.

Zahra, S., Pearce, A. (1989). Board of directors \& corporate financial performance: a review \& integrative model. Journal of Management. 15 (2), 291-334. 